\title{
Physiological and Reproductive Responses of Domyati Ducks to Different Dietary Levels of Coconut Oil as a Source of Medium-Chain Fatty Acids during Laying Period
}

\author{
K. H. El-Kholy ${ }^{1 *}$, A. I. A. Ghonim², M. A. Ahmed ${ }^{2}$, Hoda A. Gad $^{2}$, Mervat N. Ghazal ${ }^{2}$, M. A. A. El-Aik ${ }^{2}$ and Reham A.M. Ali ${ }^{3}$ \\ ${ }^{1}$ Poultry Production Depart., Fac. Agric., Damietta Univ., Damietta, 34518, Egypt \\ ${ }^{2}$ Anim. Prod. Res. Inst., Agric. Res. Centre, Dokki, Giza, 12618, Egypt \\ ${ }^{3}$ Anim. Poult. Prod. Dept., Fac. Agric. and Nat. Res., Aswan Univ., 81528, Egypt \\ *Corresponding author's Email: khelkholy@du.edu.eg; ORCID: 0000-0002-2562-2311
}

Received: 07 Jul. 2020

Accepted: 20 Aug. 2020

\begin{abstract}
The objective of this study was to determine the optimal level of coconut oil (CO) supplementation in the diet to enhance the performance of Domyati ducks. A total number of 300 Domyati ducks ( 240 females and 60 males) aged 25-week-old were randomly assigned to 4 experimental groups of three replicates, each replicate included 5 males and 20 females of Domyati ducks. The groups received CO at 0,1.0, 1.5, and 2.0\% during the experimental period. The results indicated that egg weight, egg number, and egg mass significantly increased in treated groups, compared to the control group. Furthermore, fertility and hatchability percentages were superior in 1.0, and $1.5 \% \mathrm{CO}$ groups, compared to other experimental groups. Low-density lipoprotein in ducks that received CO was significantly lower than that of the control group. It is concluded that the inclusion of $\mathrm{CO}$ at a $1.5 \%$ level could be enough and useful for improving the reproductive and physiological performance of Domyati ducks.
\end{abstract}

Keywords: Blood, Coconut oil, Ducks, Egg, hatchability, Laying period

\section{INTRODUCTION}

Ducks are the second common strain of poultry in the world and can be considered a potential source of dietary protein for humans (Ali et al., 2018). Domyati ducks are a local breed in Egypt and their meat is more favorable to the Egyptian consumers. However, the relatively high content of fat and cholesterol in meat and eggs may limit their consumption (Pagala and Nur, 2010; Aziz et al., 2012). Consumer anxiety may be eliminated by the production of duck eggs with low cholesterol levels by feeding ducks on diets containing medium-chain fatty acids (MCFA) (Li et al., 2018).

Coconut oil (CO) is considered a highly saturated oil, about $60 \%$ of its total fatty acid composition is MCFA with a chain length of 6 to 12 carbon atoms (Bhatnagar et al., 2009). CO is composed primarily of short-chain fatty acids and MCFA; lauric acid (12:0) comprises approximately $46.5 \%$ of the fatty acid content (Dauqan et al., 2011). The MCFA are directly absorbed into the portal circulation without any re-esterification in intestinal cells (Ferreira et al., 2012). The MCFAs are partly independent of the carnitine transport mechanism into the mitochondria of the liver and are rapidly and are exclusively oxidized for the production of energy (Rubin et al., 2000). However, most diets commonly contain long-chain fatty acids (LCFA) that are incorporated into chylomicrons after absorption in the small intestine where they are reesterified and then enter the blood-stream (Ferreira et al., 2012). Most LCFA are stored in the adipose tissue (Rego Costa et al., 2012). While, MCFAs are associated with reduced fat deposition and improved serum lipid profiles in humans and rats (Han et al., 2003; Takeuchi et al., 2006).

However, few researches have been conducted to study the effects of MCFA on broiler chickens, excepting that it reduces weight gain (Santos et al., 2008). In laying hens, Lee et al. (2015) found that chickens that received MCFA had greater egg protein quality (larger Haugh units), stronger egg-shells, and higher content of calcium, and reduced Escherichia coli count. Several studies showed that most of fatty acids in $\mathrm{CO}$ are potential as antibacterial (Bergsson et al., 2001), antiviral (Bartolotta et al., 2001), and immune-stimulant agents (Witcher et al., 
1996; El-Kholy et al., 2014 and 2018), which are important to fight infection. Also, MCFA inhibits the production of lipases by the bacterium (Dierick et al., 2002). As lipases are needed to allow the bacteria to attach to the intestinal wall, this process will be prohibited and the bacteria will be washed out. The immune system requires antioxidants to produce and maintain the balance of immune cells, to protect cell membranes from reactive oxygen species, and to fight microorganisms causing disease (Tugiyanti1 et al., 2016).

In addition, $\mathrm{CO}$ could improve fat digestion and performance values during the coccidiosis infection in broilers chickens (Adams et al., 1996). Few studies are available on the effects of $\mathrm{CO}$ as a source of MCFA on the physiological and reproductive parameters of Domyati ducks. Also, no studies have shown whether it is beneficial to other sources of energy for local duck breeds, especially during the laying period. Moreover, appropriate inclusion level of $\mathrm{CO}$ in laying duck's diet is not definitely known. Therefore, the current study was conducted to investigate the effect of diets containing different $\mathrm{CO}$ levels on some physiological and reproductive parameters and some egg quality traits of Domyati ducks during the laying period.

\section{MATERIALS AND METHODS}

\section{Ethical approval}

The current study protocol used in this study was approved by the Animal Care and Use Committee of Damietta University, Damietta, Egypt.

\section{Study design}

The current experimental work was carried out at El-Serw Water Fowl Research Station, Animal Production Research Institute. Agricultural Research Center, Ministry of Agriculture, Egypt; to evaluate the impact of adding different levels of $\mathrm{CO}$ on reproductive performance of Domyati duck diets during the first 3 months of egg production season (25-36 weeks of age). A total number of 300 Domyati ducks (240 females and 60 males), 25 weeks old, were weighed and randomly distributed into four experimental groups, each group contained 75 ducks. Each group was also subdivided equally into three replicates of 20 females and 5 males each. Ducks within each group were fed with different diets; G1 was fed the basal diet and served as the control group, the other three groups (G2, G3, and G4) were fed the basal diet supplemented with different levels of $\mathrm{CO}(1.0,1.5,2.0 \% / \mathrm{kg}$ feed, respectively).
Fatty acids composition in $\mathrm{CO}$ is presented in Table 1. Diets listed in Table 2 were formulated to be iso-caloric and iso-nitrogenous according to NRC (1994) and were offered in mash form throughout the experimental period. Ducks of each replicate were reared in a house $(2.3$ ducks $/ \mathrm{m}^{2}$ ) with windows and received additional artificial light to provide $17 \mathrm{~h}$ light and $7 \mathrm{~h}$ dark daily. Ducks in all treatments were reared under similar hygienic and management conditions.

Table 1. Fatty acids composition of coconut oil ${ }^{1}$

\begin{tabular}{lc}
\hline Common name & Percentage (\%) \\
\hline Caproic acid (C 6:0) & $0.4-0.6$ \\
Caprylic acid (C 8:0) & $4.6-10$ \\
Capric acid (C 10:0) & $5.0-8.0$ \\
Lauric acid (C 12:0) & $45.1-53.2$ \\
Myristic acid (C 14:0) & $16.8-21$. \\
Palmitic acid (C 16:0) & $7.5-10$ \\
Stearic acid (C 18:0) & $2.0-4.0$ \\
Oleic acid (C 18:1) & $5.0-10.0$ \\
Linoleic acid (C 18:2) & $1.0-2.5$ \\
Other (C 18:3 C 24:1) & $<0.5$ \\
\hline${ }^{1}$ According to Rossell (1985).
\end{tabular}

${ }^{1}$ According to Rossell (1985).

Table 2. Ingredients and chemical analysis of experimental diets

\begin{tabular}{|c|c|c|c|c|}
\hline \multirow[b]{2}{*}{ Ingredients (\%) } & \multicolumn{4}{|c|}{ Treatments (coconut oil levels, \%) } \\
\hline & $\begin{array}{c}0.0 \\
\left(\mathrm{G}_{1}\right)\end{array}$ & $\begin{array}{c}1.0 \\
\left(\mathrm{G}_{2}\right)\end{array}$ & $\begin{array}{c}1.5 \\
\left(\mathrm{G}_{3}\right) \\
\end{array}$ & $\begin{array}{c}2.0 \\
\left(\mathrm{G}_{4}\right)\end{array}$ \\
\hline Yellow corn & 65.05 & 63.10 & 62.13 & 60.93 \\
\hline Soybean meal & 23.91 & 26.31 & 27.51 & 27.63 \\
\hline Gluten corn & 2.30 & 0.85 & 0.12 & 0.00 \\
\hline Coconut oil & 0.00 & 1.00 & 1.50 & 2.00 \\
\hline Wheat bran & 0.00 & 0.00 & 0.00 & 0.70 \\
\hline Calcium carbonate & 6.15 & 6.15 & 6.15 & 6.15 \\
\hline Dicalcium phosphate & 1.75 & 1.75 & 1.75 & 1.75 \\
\hline Lysine & 0.00 & 0.00 & 0.00 & 0.00 \\
\hline DL.-Methionine & 0.09 & 0.09 & 0.09 & 0.09 \\
\hline Vitamin and mineral premix* & 0.30 & 0.30 & 0.30 & 0.30 \\
\hline $\mathrm{NaCl}$ & 0.35 & 0.35 & 0.35 & 0.35 \\
\hline Sodium Bicarbonate & 0.10 & 0.10 & 0.10 & 0.10 \\
\hline \multicolumn{5}{|l|}{ Calculated analysis } \\
\hline Crude protein $(\%)$ & 17.000 & 17.000 & 17.000 & 17.000 \\
\hline $\operatorname{ME}(\mathrm{Kcal} / \mathrm{Kg})$ & 2,800 & 2,800 & 2,800 & 2,800 \\
\hline Lysine $(\%)$ & 0.75 & 0.75 & 0.75 & 0.75 \\
\hline Crude fiber $(\%)$ & 3.15 & 3.10 & 3.28 & 3.33 \\
\hline Methionine (\%) & 0.35 & 0.35 & 0.35 & 0.35 \\
\hline Methionine +Cystine (\%) & 0.60 & 0.60 & 0.60 & 0.60 \\
\hline Threonine $(\%)$ & 0.27 & 0.27 & 0.27 & 0.27 \\
\hline Calcium (\%) & 2.80 & 2.80 & 2.80 & 2.80 \\
\hline Available Phosphorus (\%) & 0.45 & 0.45 & 0.45 & 0.45 \\
\hline Chlorine (\%) & 0.22 & 0.22 & 0.22 & 0.22 \\
\hline Sodium (\%) & 0.17 & 0.17 & 0.17 & 0.17 \\
\hline
\end{tabular}

*Vit+Min premix: Provided per kilogram of the diet Vit. A: 6000 IU, Vit. E (dl- $\alpha$-) Tocopherylacetate: $10 \mathrm{IU}$, menadione: $2.5 \mathrm{mg}$, Vit. D3: 2000 ICU, riboflavin: $2.5 \mathrm{mg}$, calcium Pantothenate: $10 \mathrm{mg}$, nicotinic acid :12 $\mathrm{mg}$, Choline chloride:300 mg, Vit. B12: $4 \mu \mathrm{g}$, Vit. B 6: $5 \mathrm{mg}$, thiamine: 3 $\mathrm{mg}$, folic acid: $0.50 \mathrm{mg}$, and biotin: $0.02 \mathrm{mg}$. Trace mineral $(\mathrm{mg} / \mathrm{kg}$ of diet: Mn: $80 \mathrm{mg}, \mathrm{Zn}: 60 \mathrm{mg}$, Fe: $35 \mathrm{mg}, \mathrm{Cu}: 8 \mathrm{mg}$ and Se: $0.1 \mathrm{mg}$ ). 


\section{Productive performance}

The number of eggs laid (EN) was daily recorded and also eggs were weighed from 25 to 36 weeks of age. The EN was calculated per duck for 4 weeks as follows:

EN per duck=Total EN per replicate / Number of ducks at house.

Egg weight (EW) was recorded for each replicate. Egg mass (EM) was calculated by multiplying EN by EW. The EM was expressed per duck throughout the experimental period. Feed consumption (FC) of each replicate was weekly recorded; it was then averaged and expressed in gram/duck/4 weeks. Feed conversion ratio (FCR) for egg production was also calculated during the same periods.

\section{Egg quality}

At $33^{\text {rd }}$ weeks of age, a total number of 60 eggs (15 from each treatment) were randomly taken to determine egg quality traits. During two successive days per each week during the $33^{\text {rd }}$ to $36^{\text {th }}$ weeks of age, all eggs laid by ducks of each treatment were collected and individually subjected to the following measurements and estimations. Egg was broken and the yolk was separated from albumen. Egg yolk, albumen, and shell (with its membranes) were separately weighted. Relative weights of each component (to the whole EW) were then calculated. Shell thickness was measured at the broad, narrow and the middle ends, using a micrometer. The average shell thickness for all regions was calculated. The egg shape index was calculated according to the following formula:

Egg shape index $=($ Egg width $/$ Egg length $) \times 100$

\section{Egg fertility and hatchability percentages}

A total of 300 eggs were collected from each treatment during the $34^{\text {th }}-36^{\text {th }}$ weeks of age to determine fertility and hatchability percentages. They were randomly divided into three equal replicates. Fertility percentage was determined on the $10^{\text {th }}$ day of incubation. Hatchability percentage was determined at the end of the incubation period.

\section{Plasma analysis}

At the end of the experimental period ( $36^{\text {th }}$ week), three ducks from each treatment group were randomly taken for blood sampling through wing vein. Blood samples were collected in heparinized test tubes and centrifuged at $3500 \mathrm{rpm}$ for 15 minutes to obtain blood plasma. Plasma samples were stored at $-20{ }^{\circ} \mathrm{C}$ until analysis to determine total protein (TP) and albumin (Alb) levels. The TP and Alb were determined using commercial kits supplied by Randox (Randox Laboratories Ltd, Crumlin, Co, Antrim, UK) according to Henry et al.
(1974). Globulin (Glb) concentration was estimated by subtracting the values of Alb from the corresponding values of TP. Also, the plasma was assayed for total cholesterol, triglycerides, high-density lipoprotein (HDL), and low-density lipoprotein (LDL) using standard protocol methods (Vogel and Vogel, 1997). The radioimmunoassay method was used for the determination of triiodothyronine $\left(\mathrm{T}_{3}\right)$ and thyroxin hormone $\left(\mathrm{T}_{4}\right)$ using commercial RIA kits (Medical Technology, USA). Plasma samples were analyzed for concentrations of aspartate transaminase (AST) and alanine transaminase (ALT), phosphorous, and calcium using commercial kits (Linear Chemicals, Barcelona, Spain) according to the manufacturer procedure.

\section{Statistical analysis}

Data were subjected to one-way ANOVA using the general linear model (GLM) procedure of SAS software (SAS, 2004) based on the following model:

$$
\mathrm{Y}_{\mathrm{ij}}=\mu+\mathrm{T}_{\mathrm{i}}+\mathrm{e}_{\mathrm{iJ}}
$$$$
\text { where: }
$$

$\mathrm{Y}_{\mathrm{ij}}=$ An observation; $\mu=$ Overall mean; $\mathrm{Ti}=$ Effect of treatments ( $i=1,2,3$ and 4$)$; and $e_{i j}=$ Random error component assumed to be normally distributed. Differences between the treatment groups were considered statistically different at $\mathrm{p} \leq 0.05$. The significant differences among treatments were determined by Duncan's multiple range test (Duncan, 1955).

\section{RESULTS AND DISCUSSION}

\section{Productive performance}

As shown in Table 3, EN significantly $(p \leq 0.05)$ increased in the G2 group compared to G1, G3, and G4 at the first experimental period (25-28 weeks of age). While G3 recorded the highest EN during the other experimental periods and at the overall period (25-36 weeks of age). EW significantly $(p \leq 0.05)$ decreased in the G2 group compared to G1, G3, and G4 in the first experimental period. On the other hand, ducks in G3 recorded the highest EW at both the second experimental period (29-32 weeks of age) and the overall period (Table 3). The results of the analysis indicated that the use of various dietary $\mathrm{CO}$ levels significantly $(p \leq 0.05)$ affected the EM at all experimental periods. Also, the dietary $\mathrm{CO}$ addition significantly $(\mathrm{p} \leq 0.05)$ improved FCR at all experimental periods compared to the control group. As shown in Table 3 , Domyati ducks that received the diet containing $1.5 \%$ $\mathrm{CO}(\mathrm{G} 3)$ had significantly $(\mathrm{p} \leq 0.05)$ better productive performance parameters, except FC, compared to other 
groups (G1, G2, and G4) during the overall laying period. Accordingly, $1.5 \% \mathrm{CO}$ in the diet could be considered suitable for Domyati laying ducks.

The FC values were not significantly affected by feeding different levels of $\mathrm{CO}$ during 29-32 weeks of age and the whole period from 25-36 weeks of age (Table 3). The group fed diet containing $1.0 \% \mathrm{CO}$ recorded significantly higher value of FC from 25-28 weeks of age, whereas, ducks receiving $1.5 \% \mathrm{CO}$ had significantly higher value of FC during 33- 36 weeks of age compared to the other treatments group.

The improvement of EM may be due to the higher EN and EW associated with the diet containing 1.5\% CO. These results are in agreement with Wang et al. (2009) and Lee et al. (2015) who reported that dietary supple- mentation of MCFA improved egg production in the laying hens. In contrary, Klementavičiūtè et al. (2016) reported that laying hens fed the diet supplemented with MCFA showed a low egg production rate. These differences may be due mainly to different levels of $\mathrm{CO}$ and differences in bird species. Furthermore, it is proposed that $\mathrm{CO}$ can lead to a better condition of digestion and absorption so that the ration becomes more efficient to produce eggs as mentioned by Hanczakowska et al. (2013). These effects may be attributed to a healthier and more stable gut environment created by the MCFA. Also, the antimicrobial activity of MCFA (Ferreira et al., 2012) diminishes intestinal infection pressure and improves intestinal morphology, resulting in better digestive and absorptive capacity (Batovska et al., 2009).

Table 3. Effects of supplementing coconut oil to the basal diet on productive performance of Domyati ducks during laying period.

\begin{tabular}{|c|c|c|c|c|c|c|c|}
\hline \multirow{2}{*}{ Periods (weeks of age) } & & \multicolumn{4}{|c|}{ Treatments (Coconut oil levels) } & \multirow{2}{*}{ SEM } & \multirow{2}{*}{ p-value } \\
\hline & & G1 (0\%) & G2 $(1.0 \%)$ & G3 (1.5\%) & G4 (2.0\%) & & \\
\hline \multirow{3}{*}{ Egg number/ duck } & $25-28$ & $6.8^{\mathrm{b}}$ & $8.5^{\mathrm{a}}$ & $7.7^{\mathrm{b}}$ & $7.1^{\mathrm{b}}$ & 0.12 & 0.0001 \\
\hline & $29-32$ & $11.4^{\mathrm{d}}$ & $15.9^{\mathrm{b}}$ & $17.2^{\mathrm{a}}$ & $12.2^{\mathrm{c}}$ & 0.11 & 0.0001 \\
\hline & $25-36$ & $33.5^{\mathrm{d}}$ & $41.3^{\mathrm{b}}$ & $42.2^{\mathrm{a}}$ & $35.3^{\mathrm{c}}$ & 0.15 & 0.0001 \\
\hline \multirow{2}{*}{ Egg weight (g) } & $25-28$ & $60.4^{\mathrm{a}}$ & $57.6^{\mathrm{b}}$ & $61.5^{\mathrm{a}}$ & $61.1^{\mathrm{a}}$ & 0.57 & 0.0047 \\
\hline & $29-32$ & $62.5^{\mathrm{c}}$ & $62.3^{c}$ & $68.6^{\mathrm{a}}$ & $63.2^{\mathrm{c}}$ & 0.11 & 0.0001 \\
\hline \multirow{4}{*}{ Egg mass (g) / duck } & $25-28$ & $412.7^{\mathrm{c}}$ & $487.7^{\mathrm{a}}$ & $434.6^{\mathrm{b}}$ & $433.7^{\mathrm{b}}$ & 6.35 & 0.0002 \\
\hline & $29-32$ & $712.1^{\mathrm{d}}$ & $988.5^{\mathrm{b}}$ & $1177.6^{\mathrm{a}}$ & $773.5^{\mathrm{c}}$ & 6.0 & 0.0001 \\
\hline & $33-36$ & $1019.0^{\mathrm{c}}$ & $1281.4^{\mathrm{a}}$ & $1283.1^{\mathrm{a}}$ & $1092.8^{\mathrm{b}}$ & 6.0 & 0.0001 \\
\hline & $25-36$ & $2115.1^{\mathrm{d}}$ & $2732.7^{\mathrm{b}}$ & $2904.4^{\mathrm{a}}$ & $2275.9^{c}$ & 11.42 & 0.0001 \\
\hline \multirow{2}{*}{$\mathrm{FC}(\mathrm{g}) /$ duck } & $25-28$ & $4247.0^{b}$ & $4325.0^{\mathrm{a}}$ & $4225.0^{\mathrm{d}}$ & $4233.0^{c}$ & 1.73 & 0.0001 \\
\hline & $29-32$ & 5070.0 & 5166.7 & 5035.0 & 5028.0 & 82.6 & 0.6341 \\
\hline \multirow{3}{*}{ FCR (g feed/g egg mass)/duck } & $29-32$ & $7.1^{\mathrm{a}}$ & $5.2^{\mathrm{c}}$ & $4.3^{\mathrm{d}}$ & $6.5^{\mathrm{b}}$ & 0.09 & 0.0001 \\
\hline & $33-36$ & $4.9^{\mathrm{a}}$ & $3.9^{\mathrm{c}}$ & $4.0^{\mathrm{c}}$ & $4.6^{\mathrm{b}}$ & 0.03 & 0.0001 \\
\hline & $25-36$ & $6.8^{\mathrm{a}}$ & $5.3^{\mathrm{c}}$ & $4.9^{\mathrm{d}}$ & $6.3^{\mathrm{b}}$ & 0.08 & 0.0001 \\
\hline
\end{tabular}

$\overline{\mathrm{a}, \mathrm{b}, \mathrm{c}, \mathrm{d}}$ means within rows with different superscripts are significantly different $(\mathrm{p} \leq 0.05)$. SEM: standard error mean.

\section{Egg quality traits}

The results of feeding with different levels of $\mathrm{CO}$ and their effects on egg quality traits are shown in Table 4. The group fed the diet containing $2.0 \% \mathrm{CO}$ (G4) recorded higher values of shell thickness. It was found that with increasing $\mathrm{CO}$ levels in the diet, shell thickness increased. However, there were insignificant differences in shell weight $(\%)$ for ducks that received $2.0 \%$ CO (G4) compared to the control group (G1).

These results are in agreement with Świątkiewicz et al. (2010) and Klementavičiūtė et al. (2016) who found that the addition of MCFA had a positive influence on eggshell characteristics including egg-shell weight as percentage, density, and breaking strength. This influence can probably be attributed to the increased availability of $\mathrm{Ca}$ and $\mathrm{P}$, due to a decrease in $\mathrm{pH}$ in the upper part of the intestinal tract and the stimulating effect of fatty acids on the villus height, which was observed in broilers by Hanczakowska et al. (2013).

Hence, maintaining a good quality shell throughout the production cycle is of importance for the egg consumers and producers in terms of health and economics (Hughes et al., 1986). Also, eggshell porosity is of concern during embryonic development in the breeding 
industry (Reynard and Savory, 1999). The most commonly used indicators of $\mathrm{Ca}$ metabolism in laying hens are shell quality assessment parameters (Gordon and Roland, 1998). Data presented in Table 4 also revealed that different levels of $\mathrm{CO}$ in the diet had no significant effects on EW, absolute and percentage weight of yolk and albumin, absolute shell weight, and egg shape index.
These results were in agreement with the findings of Klementavičiūté et al. (2016) who indicated that the inclusion of MCFA in birds' diet reduced egg and yolk weight, but the difference with the control group was not significant. Also, Danicke and Halle (2002) demonstrated that the yolk and albumen weights were not significantly affected by different sources or inclusion levels of lipids.

Table 4. Effects of supplementing coconut oil to the basal diet on egg quality traits of Domyati layer ducks

\begin{tabular}{|c|c|c|c|c|c|c|}
\hline \multirow{2}{*}{ Items } & \multicolumn{4}{|c|}{ Treatments (Coconut oil levels) } & \multirow[b]{2}{*}{ SEM } & \multirow[b]{2}{*}{ p-value } \\
\hline & G1 (0\%) & G2 $(1.0 \%)$ & G3 (1.5\%) & G4 (2.0\%) & & \\
\hline Egg weight (g) & 70.00 & 71.80 & 71.60 & 69.80 & 2.18 & 0.8743 \\
\hline Shell weight (g) & 9.20 & 8.80 & 9.60 & 9.80 & 0.31 & 0.1446 \\
\hline Shell weight (\%) & $13.14^{\mathrm{ab}}$ & $12.26^{\mathrm{b}}$ & $13.41^{\mathrm{a}}$ & $14.08^{\mathrm{a}}$ & 0.01 & 0.0076 \\
\hline Shell thickness (mm) & $0.29^{c}$ & $0.30^{\mathrm{bc}}$ & $0.31^{\mathrm{ab}}$ & $0.32^{\mathrm{a}}$ & 0.01 & 0.0133 \\
\hline Yolk weight $(\mathrm{g})$ & 23.20 & 24.60 & 24.00 & 24.60 & 0.90 & 0.6618 \\
\hline Yolk weight $(\%)$ & 33.25 & 34.26 & 33.54 & 35.18 & 0.01 & 0.4953 \\
\hline Albumin weight (g) & 37.60 & 38.40 & 38.00 & 35.40 & 1.47 & 0.4977 \\
\hline Albumin weight (\%) & 53.61 & 53.48 & 53.05 & 50.74 & 0.01 & 0.1834 \\
\hline Egg shape index & 0.78 & 0.78 & 0.79 & 0.79 & 0.02 & 0.9367 \\
\hline
\end{tabular}

$\overline{\mathrm{a}, \mathrm{b}, \mathrm{c}, \mathrm{d}}$ means within rows with different superscripts are significantly different $(\mathrm{p} \leq 0.05)$. SEM: standard error mean.

\section{Reproductive traits}

There were significant differences in fertility percentages among the treatment group as shown in Table 5. Also, two CO levels (1.0 and 1.5\%) significantly increased $(\mathrm{p} \leq 0.05)$ hatchability percentage of set and fertile eggs as compared to both control and group fed $2.0 \% \mathrm{CO}$ in the diet. This supports the previous findings that the incorporation of CO-derived MCFA into hen's diet is readily utilized by the embryos (Ding and Lilburn, 1997). It is clear from the results that, inclusion levels of 1.0 and $1.5 \% \mathrm{CO}$ in the diet could be considered suitable for hatching eggs, where, the groups fed diet contained 1.0 and $1.5 \%$ CO showed a good quality of shell thickness and high percentages of hatchability as compared to the other treatment groups. It was found that the hatchability of thick-shelled eggs is higher than that of thin-shelled eggs (Narushin's and Romanov, 2002). It was reported that reduction in egg-shell quality decreases hatchability and is associated with the weakening of the embryos (Peebles et al., 1987). In contrary, Yamak et al. (2016) and Ergun and Yamak (2017) indicated that differences in hatching rates of eggs with different shell thicknesses were not statistically significant.

\section{Blood plasma parameters}

Some blood plasma parameters of Domyati layer ducks were influenced by diets supplemented with different levels of CO (Table 6). However, no significant differences in plasma $\mathrm{T}_{3}, \mathrm{~T}_{4}, \mathrm{P}, \mathrm{Ca}, \mathrm{ALT}, \mathrm{AST}, \mathrm{TP}, \mathrm{Alb}$, and Glb values were observed among the treatment groups. The ALT and AST values were 20.2-23.9 and 75.7-87.0 U/l throughout the whole experimental period, respectively. These results are in agreement with those of Ali et al. (2018) who found that ALT and AST values varied between 20.2 to $24.3 \mathrm{U} / 1$ and 83.3 to $88.1 \mathrm{U} / \mathrm{l}$, respectively. Regarding the effect of dietary $\mathrm{CO}$ on lipid profile, no significant differences were observed in plasma cholesterol and triglyceride (Table 6). However, the groups fed with the diet containing $2.0 \% \mathrm{CO}$ recorded significantly $(\mathrm{p} \leq 0.05)$ higher and lower values of HDL and LDL, respectively, as compared to $1.0 \% \mathrm{CO}$ and control group. Moreover, no significant differences were observed between G1 and G2 in HDL and LDL values.

Wang et al. (2015) showed that with increasing CO levels, serum levels of total cholesterol, LDL, and LDL/HLDL linearly decreased. In general, usage of CO at some levels is a popular concept that is believed to increase the productive and reproductive performance of birds. Similarly, the administration of some levels for long periods is believed to be more effective without considering the other adverse effects on the birds. Previous studies have shown some benefits such as immune modulation and anti-inflammatory effects. Besides efficacy, these supplements also have to be safe for the animals, consumers of products, and the environment. 
El-Kholy et al., 2020

Table 5. Effects of coconut oil supplemented to basal diet on fertility and hatchability traits of Domyati duck eggs.

\begin{tabular}{|c|c|c|c|c|c|c|}
\hline \multirow{2}{*}{ Items } & \multicolumn{4}{|c|}{ Treatments (Coconut oil levels \%) } & \multirow[b]{2}{*}{ SEM } & \multirow[b]{2}{*}{ p-value } \\
\hline & G1 $(0 \%)$ & G2 $(1.0 \%)$ & G3 $(1.5 \%)$ & G4 $(2.0 \%)$ & & \\
\hline Fertility (\%) & $93.0^{\mathrm{b}}$ & $96.0^{\mathrm{a}}$ & $96.0^{\mathrm{a}}$ & $94.0^{\mathrm{b}}$ & 0.58 & 0.0139 \\
\hline Hatchability of fertile eggs (\%) & $75.4^{\mathrm{b}}$ & $79.2^{\mathrm{a}}$ & $80.2^{\mathrm{a}}$ & $76.7^{\mathrm{b}}$ & 0.61 & 0.0018 \\
\hline
\end{tabular}

$\overline{\mathrm{a}, \mathrm{b}, \mathrm{c}, \mathrm{d}}$ means within rows with different superscripts are significantly different $(\mathrm{p} \leq 0.05)$. SEM: standard error mean.

Table 6. Effects of supplementing coconut oil to the basal diet on some blood plasma parameters of Domyati ducks during laying period

\begin{tabular}{|c|c|c|c|c|c|c|}
\hline \multirow{2}{*}{ Items } & \multicolumn{4}{|c|}{ Treatments (Coconut oil levels \%) } & \multirow{2}{*}{ SEM } & \multirow{2}{*}{ p-value } \\
\hline & G1 (0\%) & G2 (1.0\%) & G3 (1.5\%) & G4 (2.0\%) & & \\
\hline $\mathrm{T}_{3}(\mathrm{ng} / \mathrm{ml})$ & 3.30 & 3.20 & 3.30 & 3.20 & 0.22 & 0.9804 \\
\hline $\mathrm{T}_{4}(\mathrm{ng} / \mathrm{ml})$ & 20.20 & 18.70 & 18.40 & 19.10 & 1.17 & 0.7132 \\
\hline $\mathrm{Pi}$ & 5.70 & 5.80 & 6.00 & 6.20 & 0.25 & 0.4348 \\
\hline $\mathrm{Ca}$ & 21.60 & 20.60 & 22.60 & 21.80 & 1.18 & 0.6065 \\
\hline $\operatorname{ALT}(\mathrm{U} / \mathrm{l})$ & 23.60 & 22.20 & 21.50 & 21.90 & 1.99 & 0.8930 \\
\hline Cholesterol (mg/dl) & 175.6 & 175.9 & 178.1 & 170.1 & 6.33 & 0.8305 \\
\hline $\mathrm{HDL}(\mathrm{mg} / \mathrm{dl})$ & $60.60^{\mathrm{b}}$ & $60.80^{\mathrm{b}}$ & $67.70^{\mathrm{a}}$ & $67.90^{\mathrm{a}}$ & 1.87 & 0.0336 \\
\hline LDL (mg/dl) & $91.50^{\mathrm{a}}$ & $90.40^{\mathrm{a}}$ & $83.80^{\mathrm{ab}}$ & $76.30^{\mathrm{b}}$ & 3.49 & 0.0507 \\
\hline Total protein $(\mathrm{TP}, \mathrm{g} / \mathrm{dl})$ & 5.14 & 5.73 & 5.80 & 5.77 & 0.25 & 0.3618 \\
\hline Albumin (Alb, g/dl) & 3.06 & 3.50 & 3.50 & 3.60 & 0.25 & 0.1095 \\
\hline
\end{tabular}

$\overline{\mathrm{a}, \mathrm{b}, \mathrm{c}, \mathrm{d}}$ means within rows with different superscripts are significantly different $(\mathrm{p} \leq 0.05)$. SEM: standard error mean.

\section{CONCLUSION}

Inclusion of coconut oil at a level of $1.5 \% / \mathrm{kg}$ feed to diet can improve the physiological and reproductive performance of local Domyati ducks during the laying period.

\section{Competing interests}

The authors declare that they have no conflict of interest.

\section{Authors' contributions}

Khaled H. El-Kholy designed the proposal of this study. Aymen I. Ghonim; Mahmoud A. Atef.; Hoda A. Gad.; Mervat N. Ghazal; Mosad A. El-Aik and Reham A. Ali developed the concept for the manuscript. Khaled $\mathrm{H}$. El-Kholy and Ayman I. Ghonim wrote the manuscript.

\section{REFERENCES}

Adams BYC, Vahl HA, and Veldman A (1996). Interaction between nutrition and Eimeria acervulina infection in broiler chickens: Diet compositions that improve fat digestion during Eimeria acervulina infection. British Journal of Nutrition, 75: 875-880. DOI: https://doi.org/10.1079/BJN19960193

Ali WAH, Ali KH AA, Amal M Hekal, Fadila M Easa, El-Aik MAA and Reham AM Ali (2018). Productive and physiological response of Pekin and Domyati ducks to dietary supplementation of excess iodine during laying period. Egyptian Poultry Science, 38: 11-33. DOI: https://doi.org/10.21608/EPSJ.2018.5710

Aziz Z, Cyriae S, Beena V and Philomina PT (2012). Comparison of cholesterol content in chicken, duck and quail eggs. Journal of Veterinary Animal Science,43:64-66. Available at: https://journals.cvaslibrary.com/1 43 15.pdf

Bartolotta S, Garcia CC, Candurra NA and Damonte EB (2001). Effect of fatty acids on arenavirus replication: inhibition of virus C.C. production by lauric acid. Archives of Virology, 146: 777-790. DOI: https://doi.org/10.1007/s007050170146

Batovska DI, Todorova IT, Tsvetkova IV and Najdenski HM (2009). The bacterial study of the medium chain fatty acids and their 1 monoglycerides: Individual effects and synergistic relationships. Polish Journal Microbiology, 58: 43-47. Available at: https://pubmed.ncbi.nlm.nih.gov/19469285/

Bergsson G, Arnfinnsson J, Steingimsson O and Thormar H (2001). In vitro killing of Candida albicans by fatty acids and monoglycerides. Antimicrobial Agents Chemotherapy, 45: 32093212. DOI: 10.1128/AAC.45.11.3209-3212.2001

Bhatnagar AS, Kumar PKP, Hemavathy J and Krishna AGG (2009). Fatty acid composition, oxidative stability, and radical scavenging activity of vegetable oil blends with coconut oil. Journal of American Oil Chemists Society, 86: 991-999. DOI: https://doi.org/10.1007/s11746-009-1435-y 
Danicke S and Halle I (2002). Effects of iso-energetic low-fat feed, soybean oil or palm oil containing feed offered to laying hens, either separately or for self-selection, on feed intake, laying and reproductive performance and on egg quality. Landbauforschung Volkenrode, 52: 239-247. Available at: https://literatur.thuenen.de/digbib_extern/zi028458.pdf

Dauqan EMA, Sani HA, Abdullah A and Kasim ZM (2011). Fatty acids composition of four different vegetable oils (red palm olein, palm olein, corn oil and coconut oil) by gas chromatography. Food and Nutrition Sciences, 2: 253-258. $\quad$ DOI: https://doi.org/10.4236/fns.2011.24036

Ding ST and Lilourn MS (1997). Inclusion of coconut oil in diets for turkey breeders and its effects on embryonic yolk and liver fatty acids. Poultry Science, 76: 1714-1721. DOI: https://doi.org/10.1093/ps/76.12.1714

Duncan DB (1955). Multiple range and multiple F. test. Biometrics, 11:142.

El-Kholy KH, Mervat N Ghazal, Morsy WA, Nehad A Ramadan and Ali WAH (2014). Effect of different dietary levels of coconut oil as a source of medium chain fatty acids on some production and physiological traits of growing rabbits. Egyptian Journal Rabbit Science, 24: 67-88. Available at: https://www.researchgate.net/publication/272679501

El-Kholy KH, Hoda A Gad, Atef M, Reham AM Ali and Mervat N Ghazal (2018). Physiological and immunological performance of Domyati ducklings fed different levels of coconut oil. Egyptian Poultry Science, 38: 847-860. DOI: https://doi.org/10.21608/EPSJ.2018.17108

Ergun OF and Yamak US (2017). The effect of eggshell thickness on hatchability of quail eggs. Veterinary World, 10: 1114-1117. DOI: https://doi.org/10.14202/vetworld.2017.1114-1117

Ferreira L, Lisenko K, Barros B, Zangeronimo M, Pereira M and Sousa R (2012). Influence of medium-chain triglycerides on consumption and weight gain in rats. A systematic review. Journal Animal Physiology Animal Nutrition, 98:1-8. DOI: https://doi.org/10.1111/jpn.12030

Gordon RW and Roland DASR (1998). Influence of supplemental phytase on calcium and phosphorus utilization in laying hens. Poultry Science, 77 : 290-294. DOI: https://doi.org/10.1093/ps/77.2.290

Han J, Hamilton JA, Kirkland JL, Corkey BE and Guo W (2003). Medium-chain oil reduces fat mass and down-regulates expression of adipogenic genes in rats. Obesity Research, 11:734-744. DOI: https://doi.org/10.1038/oby.2003.103

Hanczakowska E, Szewczyk A, Świątkiewiczl M and Okoń Polish K (2013). Short- and medium-chain fatty acids as a feed supplement for weaning and nursery pigs. Journal of Veterinary Science, 16: 647-654. DOI: https://doi.org/10.2478/pjvs-2013-0092

Henry RJ, Canmon DC and Winkelman JW (1974). Principles and Techniques, Harper and Row. Clinical Chemistry, p. 415.

Hughes BO, Gilbert AB and Brown MF (1986). Categorisation and causes of abnormal egg shells: Relationship with stress. British Poultry Science, 27: 325-337. DOI: https://doi.org/10.1080/00071668608416885

Klementavičiūtė J, Gružauskas R, Šašytė V, Daukšienė A, Kliševičiūtė V, Racevičiūtè-Stupelienè A, Šlapkauskaitė J and Dovidaitienè G (2016). Effect of medium chain fatty acids and emulsifier on quality parameters of laying hens eggs. Veterinary Medicine Zootechnics, 95: 73-77. Available at: https://vetzoo.lsmuni.lt/data/vols/2016/073/pdf/klementaviciute2.pd $\underline{\mathrm{f}}$

Lee SI, Kim HS and Kim I (2015). Microencapsulated organic acid blend with MCFAs can be used as an alternative to antibiotics for laying hens. Turkish Journal of Veterinary Animal Science, 39: 520-527. DOI: https://doi.org/0.3906/vet-1505-36

Li H, Liu Y, Zhang X,Xu Q, Zhang Y, Xue C and Guo C (2018). Medium-chain fatty acids decrease serum cholesterol via reduction of intestinal bile acid re-absorption in mice. Journal of Nutrition and Metabolism, 5: 15-37. DOI: https://doi.org/10.1186/s12986$\underline{018-0267-\mathrm{x}}$

Narushin's VG and Romanov MN (2002). Egg physical characteristics and hatchability. World's Poultry Science Journal, 58: 297-303. DOI: https://doi.org/10.1079/WPS20020023

NRC (1994). Nutrient requirements of poultry. $9^{\text {th }}$ revised edition. National Academy Press, Washington, DC. DOI: https://doi.org/10.17226/2114

Pagala MA and Nur I (2010). Pengaruh kitosan asal cangkang udang terhadap kadar lemak dankolesterol darah itik. Warta-Wiptek, 18:26-31. Available at: https://www.academia.edu/43265966/

Peebles ED, Brake J and Gildersleeve RP (1987). Effects of eggshell cuticle removal and incubation humidity on embryonic development and hatchability of broilers. Poultry Science, 66: 834840. DOI: https://doi.org/10.3382/ps.0660834

Rego Costa AC, Rosado EL and Soares-Mota M (2012). Influence of the dietary intake of medium chain triglycerides on body composition, energy expenditure and satiety. A systematic review. Nutrition Hospitals, 27:103-108. DOI: https://doi.org/10.3305/nh.2012.27.1.5369

Reynard M and Savory CJ (1999). Stress-induced oviposition delays in laying hens: Duration and consequences for eggshell quality. British Poultry Science, 40: 585-591. DOI: https://doi.org/10.1080/00071669986945

Rossell JB (1985). Fractionation of lauric oils. Journal American Oil Chemists $\quad$ Society, 62: 385-390. DOI: https://doi.org/10.1007/BF02541409

Rubin M, Moser A, Vaserberg N, Greig F, Levy Y, Spivak H, Ziv Y and Lelcuk S (2000). Long-chain fatty acids, in long-term home parenteral nutrition: A double-blind randomized cross-over study. Nutrition, 16: 95-100. DOI: https://doi.org/10.1016/s08999007(99)00249-x

SAS (2000). SAS /STAT User's Guide (Release 8.2). SAS Institute Cary North Carolina, USA.

Santos SDF, Donoghue AM, Venkitanarayanan K, Dirain ML, ReyesHerrera I, Blore PJ and Donoghue DJ (2008). Caprylic acid supplemented in feed reduces enteric Campylobacter jejuni colonization in ten-day-old broiler chickens. Poultry Science, 87: 800-804. DOI: https://doi.org/10.3382/ps.2007-00280.

Świątkiewicz S, Koreleski J and Arczewska A (2010). Laying performance and egg shell quality in laying hens fed diets supplemented with prebiotics and organic acids. Czech Journal of Animal Science, 55: 294-306. DOI: https://doi.org/10.17221/207/2009-CJAS

Takeuchi H, Noguchi O, Sekine S, Kobayashi A and Aoyama T (2006). Lower weight gain and higher expression and blood levels of adiponectin in rats fed medium-chain TAG compared with longchain TAG. Lipids, 41: 207-212. Available at: https://link.springer.com/article/10.1007/s11745-006-5089-3

Tugiyantil E, Yuwanta T, Zuprizal M, Rusman T, and Ismoyowati I (2016). Effect of $\alpha$-tocopherol and ascorbic acids on performance and blood immunity profile of male native Muscovy duck. Journal Indonesian of Tropical Animal Agriculture, 41: 145-152. DOI: https://doi.org/10.14710/jitaa.41.3.145-152

Vogel G and Vogel WH (1997). Influence of lipid metabolism. In: Drug Discovery and Evaluation Pharmacological Assay, Springer-Verly, Berloin, pp. 604-608. Available at: https://link.springer.com/referenceworkentry/10.1007/978-3-31905392-9_47 
Wang Y, Ghoshal S, Ward M, de Villiers W, Woodward $\mathrm{J}$ and Eckhardt E (2009). Chylomicrons promote intestinal absorption and systemic dissemination of dietary antigen (ovalbumin) in mice. PLoS One, 4: 8442 .

DOI: https://doi.org/10.1371/journal.pone.0008442

Wang J, Wang X, Li J, Chen Y, Yang W and Zhang L (2015). Effects of dietary coconut oil as a medium-chain fatty acid source on performance, carcass composition and serum lipids in male broilers. Asian Australas. Journal of Animal Science, 28: 223-230. DOI: https://doi.org/10.5713/ajas.14.0328
Witcher KJ, Novick RP and Schlievert PM (1996). Modulation of immune cell proliferation by glycerol monolaurate. Clinical Diagnostic Laboratory Immunology, 3:10-13. DOI: https://doi.org/10.1128/CDLI.3.1.10-13.1996

Yamak US, Boz MA, Ucar A, Sarica M and Onder H (2016). The effect of eggshell thickness on the hatchability of guinea fowl and pheasants. Brazilian Journal of Poultry Science, 2: 49-53. DOI: https://doi.org/10.1590/1806-9061-2015-0214 